\title{
ANALISIS TINGKAT KERAWANAN LONGSOR LERENG DI DESA TIPAR KIDUL KECAMATAN AJIBARANG
}

\section{ANALYSIS OF LANDSLIDE VULNERABILITY LEVEL IN TIPAR KIDUL VILLAGE AJIBARANG SUB-DISTRICT}

\author{
Rizqi Purnama Putra ${ }^{1}$, Amris Azizi ${ }^{2}$, M. Agus Salim A.F \\ ${ }^{123}$ Program Studi S1 Teknik Sipil, Fakultas Teknik dan Sains \\ Universitas Muhammadiyah Purwokerto
}

\section{Informasi Artikel \\ Dikirim, \\ Direvisi, \\ Diterima,}

\section{Korespondensi Penulis:}

Rizqi Purnama Putra Program Studi Teknik Sipil Universitas Muhammadiyah Purwokerto

JL. K.H. Ahmad Dahlan

Purwokerto, 53182

Email:

rizqipurnamaputra13@gmail.com

\begin{abstract}
ABSTRAK
Bencana tanah longsor merupakan salah satu bencana alam yang banyak menimbulkan korban jiwa dan harta benda. Gerakan tanah dalam bentuk longsor lahan sangat banyak di Indonesia. Hal ini disebabkan karena Indonesia merupakan daerah subdiksi, sehingga mempunyai topografi yang bergunung-gunung yang menjadikan lahan mempunyai lereng yang landai sampai curam, dengan curah hujan yang relatif tinggi dan kondisi geomorfologi yang cukup komplek di beberapa wilayah Indonesia. Desa Tipar Kidul merupakan salah satu Desa di Kecamatan Ajibarang yang termasuk kawasan kerentanan terhadap bencana tanah longsor. Metode yang digunakan dalam penelitian ini adalah metode survei, yaitu penelitian tidak melakukan suatu percobaan tetapi lebih kearah pendalaman suatu kasus atau keadaan dan dideskripsikan secara mendalam. Data yang dikumpulkan di maksudkan untuk mendapatkan faktor kondisi alam dan aktivitas manusia yang dapat menjadi faktor penyebab terjadinya tanah longsor dan analisis dengan pendekatan yang disusun oleh Direktorat Jenederal Penataan Ruang tahun 2008. Tahapan pelaksanaan terdiri dari persiapan, studi pustaka \& literatur, pengumpulan data, pengolahan data, hasil dan pembahasan, kesimpulan. Penelitian ini bertujuan untuk mengetahui seberapa besar tingkat kerawanan longsor di Desa Tipar Kidul. Analisis data dilakukan untuk menetapkan tipologi zona berpotensi longsor dan menentukan klasifikasi tingkat kerawanan terhadap longsor. Data melalui pengamatan langsung di lapangan, dan data sekunder dari berbagai instansi yang terkait maupun diperoleh dari aplikasi bantu yaitu Arc GIS. Dari hasil penelitian, analasis dan pembahasan diperoleh tingkat kerawanan longsor antara 1,975 -2,24, maka tingkat kerawanan zona berpotensi longsor Desa Tipar Kidul tergolong sedang.
\end{abstract}

Kata Kunci : Kerawanan, Longsor, Lereng

\section{ABSTRACT}

Landslide disaster is one of the natural disasters that causes many casualties and property. Soil movements in the form of land slides are very numerous in Indonesia. This is because Indonesia is a subdiction, so it has mountainous topography that makes land have sloping to steep slopes, with relatively high rainfall and fairly complex geomorphological conditions in several parts of Indonesia. Tipar Kidul Village is one of the villages in Ajibarang Subdistrict which is included in the area of vulnerability to landslides. The method used in this study is a survey method, the research does not do an experiment but rather towards the deepening of a case or condition and is described in depth. The data collected is intended to obtain factors of natural conditions and human activities that can be a factor causing landslides and analysis with an approach compiled by the Directorate General of Spatial Planning in 2008. Stages of implementation consist of preparation, literature study \& literature, data collection, data processing, results and discussion, conclusions. This study aims to determine how much the level of landslide vulnerability in the village of Tipar Kidul. Data analysis was performed to determine the typology of a potential landslide zone and determine the classification of the level of vulnerability to landslides. Data through direct observation in the field, and secondary data from various agencies that are related or obtained from assistive applications, namely Arc GIS. From the results of the study, analysis and discussion obtained the level of landslide vulnerability between $1,975-2.24$, then the level of vulnerability of potential landslide zones of Tipar Kidul Village is classified as moderate. 
Keyword : Merupakan Vulnerability, Landslides, Slopes

\section{PENDAHULUAN}

Pada Bencana alam merupakan peristiwa alam yang diakibatkan oleh proses alam, baik yang terjadi oleh alam itu sendiri maupun diawali oleh tindakan manusia, yang menimbulkan bahaya dan resiko longsor terhadap kehidupan manusia baik harta benda maupun jiwa. Karakteristik bencana alam ditentukan oleh keadaan lingkungan fisik seperti ; iklim, topografi, geologi tanah, data air, penggunaan lahan dan aktifitas manusia.

Dalam kerangka manajemen bencana, Undang-Undang No. 24 Tahun 2007 tentang Penanggulangan Bencana, mendefinisikan bencana sebagai peristiwa atau rangkaian peristiwa yang mengancam dan mengganggu kehidupan dan penghidupan masyarakat yang disebabkan, baik oleh faktor alam dan/atau faktor non alam maupun faktor manusia sehingga mengakibatkan timbulnya korban jiwa manusia, kerusakan lingkungan, kerugian harta benda, dan dampak psikologis. Bencana alam antara lain berupa gempa bumi, tsunami, gunung meletus, banjir, kekeringan, angin topan, dan tanah longsor. Berdasarkan definisi di atas maka potensi bencana adalah keadaan, atau kondisi alam yang memungkinkan terjadinya bencana. Misalnya kondisi tanah yang labil dengan lereng yang curam adalah daerah yang rawan longsor, apabila terjadi cuaca ekstrim berupa curah hujan yang tinggi maka kemungkinan akan terjadi longsor. Peningkatan curah hujan berkorelasi positif terhadap kelembaban tanah sebelum terjadi longsor (Ponziani et al, 2012; Lepore, 2013).

Tanah longsor adalah perpindahan material pembentuk lereng berupa batuan, bahan rombakan, tanah, atau material campuran tersebut, bergerak ke bawah atau keluar lereng. Gerakan tanah dalam bentuk longsor lahan sangat banyak di Indonesia. Hal ini disebabkan karena Indonesia merupakan daerah subdiksi, sehingga mempunyai topografi yang bergunung-gunung yang menjadikan lahan mempunyai lereng yang landai sampai curam, dengan curah hujan yang relatif tinggi dan kondisi geomorfologi yang cukup komplek di beberapa wilayah Indonesia, longsor lahan dianggap merupakan suatu hal yang sudah biasa terjadi.

Bencana tanah longsor terjadi di Desa Tipar Kidul Kecamatan Ajibarang Kabupaten Banyumas pada tanggal 3 Oktober 2016 pukul 06.00. Di Kecamatan Ajibarang, tanah longsor terjadi di Desa Tipar kidul dan Darmakeradenan. Di Tipar Kidul, dapur rumah milik Jatinah (50) warga RT 03 RW 10 terbawa longsor setelah tebing yang berada di atas dapur tersebut longsor pada Senin (3/10) pukul 06.00. tidak ada korban jiwa dalam peristiwa tersebut, namun kerugian diperkirakan mencapai Rp 25 juta. Kepala Desa Tipar Kidul Riyanto mengatakan, selain mengancam rumah Jatinah, longsor tersebut juga mengenai masjid Al Isro yang berada dibawah tebing.(Radar Banyumas, 2016).

Tujuan dari penelitian ini adalah untuk mengetahui dan menganalisis tingkat kerawanan longsor di Desa Tipar Kidul, Kecamatan Ajibarang. Hasil penelitian ini diharapkan dapat memberi masukan kepada pengambil kebijakan dalam mitigasi dan upaya-upaya penanggulangan bencana tanah longsor, khususnya di Desa Tipar Kidul Kecamatan Ajibarang. Hasil penelitian ini diharapkan pula menjadi bahan referensi dalam studi, penelitian, dan upaya-upaya pencegahan dan penaggulangan longsor lereng.

\section{METODE PENELITIAN}

Penelitian ini menggunakan metode survei dan menggunakan aplikasi bantu Arc GIS. Data yang dikumpulkan di maksudkan untuk mendapatkan faktor kondisi alam dan aktivitas manusia yang dapat menjadi faktor penyebabterjadinya tanah longsor dan analisis dengan pendekatan yang disusun oleh Direktorat Jenederal Penataan Ruang (2008). Pendekatan ini menetapkan kawasan rawan bencana longsor atas zona-zona berdasarkan karakter dan kondisi fisik alaminya sehingga pada setiap zona akan berbeda dalam penentuan struktur ruang dan pola ruangnya serta jenis dan intensitas kegiatan yang dibolehkan, dibolehkan dengan persyaratan, atau yang dilarang.

\subsection{Waktu dan Lokasi Penelitian}

Penelitian dilakukan pada bulan Mei - Juni 2020, dan lokasi penelitian adalah Desa Tipar Kidul Kecamatan Ajibarang Kabupaten Banyumas.

\subsection{Alat dan Bahan Penelitian}

Alat yang digunakan meliputi form survei dan alat tulis untuk pencatatan kondisi eksisting lapangan/lokasi penelitian dan wawancara dengan narasumber. Untuk pengukuran dan pengambilan data lokasi kondisi kemiringan lereng menggunakan aplikasi Arc GIS.

\subsection{Analisis Data}

Analisis data dalam penelitian ini adalah deskriptif kualitatif. Analisis deskriptif akan menghasilkan data 
yang menjelaskan secara rinci fakta yang ada di lapangan. Data penelitian deskriptif diambil berdasarkan fenomena yang ada dan teramati. Analisis data dilakukan untuk menentukan klasifikasi tingkat kerawanan terhadap longsor dengan pendekatan yang disusun oleh Direktorat Jenderal Penataan Ruang (2008). Tingkat kerawanan adalah ukuran yang menyatakan besar-kecilnya kemungkinan suatu zona berpotensi longsor mengalami bencana longsor, serta kemungkinan besarnya korban dan kerugian apabila terjadi bencana longsor yang diukur berdasarkan indikator-indikator tingkat kerawanan fisik alami dan tingkat kerawanan karena aktifitas manusia atau tingkat risiko. Untuk mengukur tingkat kerawanan berdasarkan aspek fisik akami ditetapkan 7 (tujuh) indikator yakni faktor-faktor : kemiringan lereng, kondisi tanah, batuan penyusun lereng, curah hujan, tata air lereng, kegempaan dan vegetasi. Sedangkan untuk mengukur tingkat kerawanan berdasarkan aspek aktifitas manusia yakni tingkat risiko kerugian manusia dari kemungkinan kejadian longsor ditetapkan 7 (tujuh) indikator : pola tanam, penggalian dan pemotongan lereng, pencetakan kolam, drainase, pembangunan konstruksi, kepadatan penduduk, dan usaha mitigasi.

\subsection{Bagan Alir Penelitian}

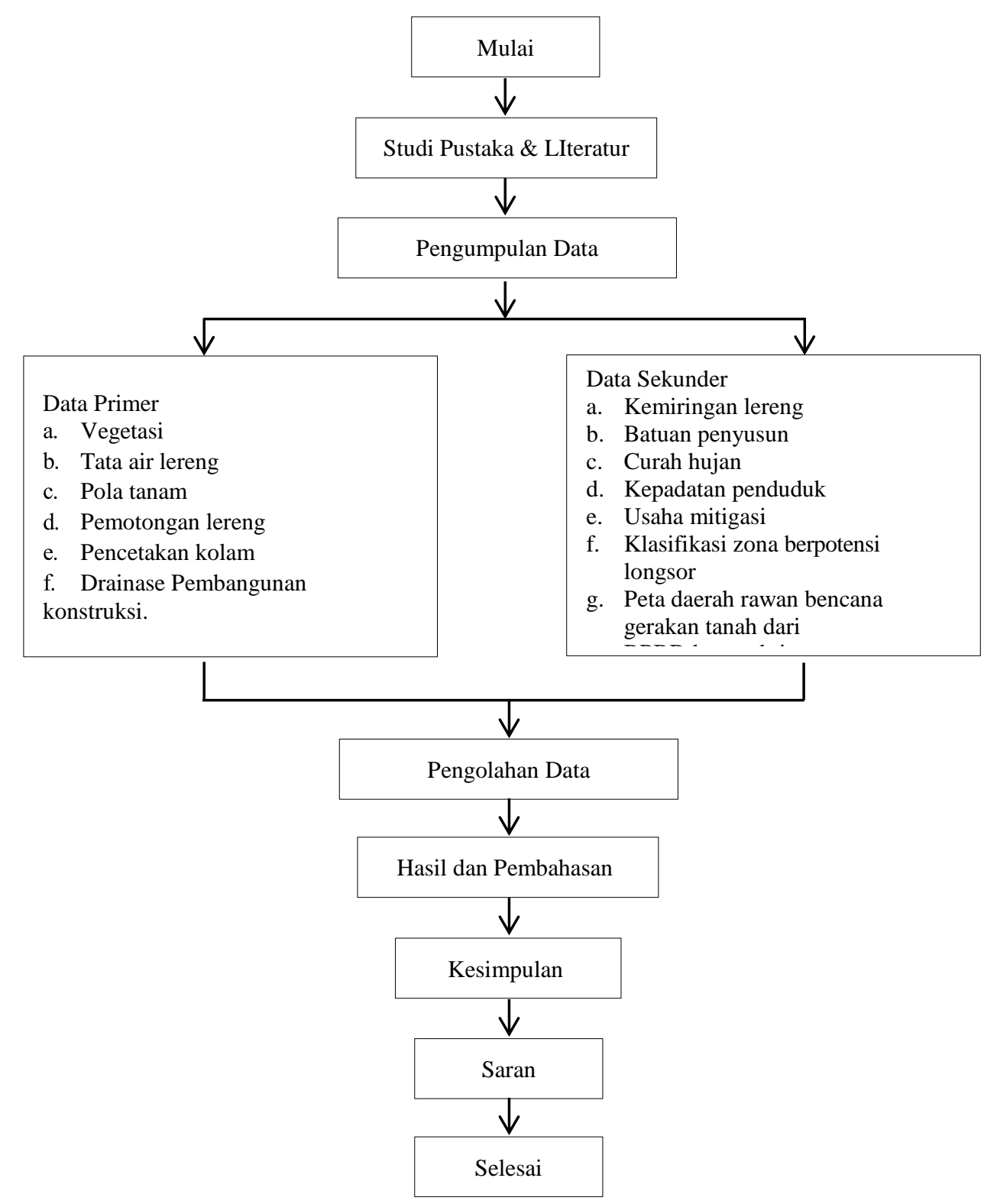

Gambar 1. Diagram alur penelitian 
3. HASIL DAN PEMBAHASAN

3.1. Letak dan Kondisi Umum Desa Tipar Kidul

Desa Tipar Kidul terletak di bagian selatan Kecamatan Ajibarang. Disebelah utara berbatasan dengan Desa Karangbawang dan Desa Darmakradenan, disebelah timur berbatasan dengan Desa Sawangan, sedangkan sebelah selatan berbatasan dengan wilayah Kecamatan Wangon. Desa Tipar Kidul mempunyai luas wilayah 1020,14 ha, yang terdiri dari 10 Dusun, 13 RW dan 62 RT dengan jumlah penduduk 11.081 orang. (BPS Kabupaten Banyumas).

\subsection{Kondisi Fisik Desa Tipar Kidul \\ Kemiringan lereng}

Desa Tipar Kidul merupakan daerah yang memiliki perbukitan dan lereng- lereng yang relatif landai, dengan kemiringan antara $0-20 \%$.

\section{Kondisi tanah}

Menurut sistem Taksonomi Tanah (USDA) 2014, pada umumnya jenis tanah di Desa Tipar Kidul adalah jenis tanah Oxic Dystrudepts (Latosol Oksik) dan Aquic Dystrudepts (Latosol Gleik) yang berlokasi di titik 1 dan jenis tanah Typic Endoaquepts (Aluvial Hidrik) dan Typic Dystrudepts (Latosol Rodik) yang berlokasi di titik 2 dan 3.

\section{Batuan penyusun lereng}

Batuan yang terdapat di Desa Tipar Kidul didominasi oleh jenis batu formasi halang yaitu jenis tanah batu pasir andesit, konglomerat tufan dan napal, bersisipan batu pasir. Di atas bidang perlapisan batu pasir terdapat bekas- bekas cacing.(Sumber: Peta Geologi Purwokerto \& Tegal)

\section{Kondisi hidrologi dan klimatologi}

Secara umum curah hujan rata-rata Desa Tipar Kidul dalam beberapa tahun terakhir cukup tinggi yaitu $2655 \mathrm{~mm} /$ tahun yang diperoleh dari stasiun penangkaran hujan bendung tajum yang terletak di Desa Tipar Kidul. Desa Tipar Kidul termasuk salah satu desa yang dilalui sungai, sehingga kebutuhan air untuk pertanian sawah berasal dari aliran sungai dan tadah hujan. Sedangkan kebutuhan air untuk rumah tangga dipenuhi dari mata air dan sumur galian. (Sumber: Analisis 2020).

\section{Kondisi topografi}

Desa Tipar Kidul Kecamatan Ajibarang mempunyai bentuk topografi perbukitan terjal yang berderetan dengan perbukitan di Desa Sawangan dan Desa Darmakeradenan. Perbukitan di Desa Tipar Kidul menempati area seluas $10,2014 \mathrm{~km}^{2}$ dengan kemiringan lereng alami perbukitan bervariasi antara $0-20 \%$.

\section{Kondisi tata air lereng}

Lereng-lereng di Desa Tipar Kidul termasuk daerah yang jarang muncul rembesan air pada lereng, terutama pada bidang kontak antara batuan kedap dengan lapisan tanah.

\section{Kondisi kegempaan}

Desa Tipar Kidul Kecamatan Ajibarang merupakan kawasan dengan tingkat risiko kegempaan rendah. Rencana Tata Ruang Wilayah (RTRW) Kabupaten Banyumas tahun 2005 - 2015 menegaskan bahwa Wilayah Kabupaten Banyumas bukan merupakan kawasan yang rawan terhadap bencana alam gempa bumi.

\section{Kondisi vegetasi}

Desa Tipar Kidul merupakan Desa sekitar hutan dengan tutupan vegetasi yang beragam. Keragaman vegetasi terjadi secara alami dan tidak alami. Pada lahan - lahan non pertanian, terutama di bagian perbukitan dengan lahan yang miring, vegetasi terdiri dari berbagai macam tumbuhan dengan penyebaran yang tidak teratur. Pada umumnya tumbuhan adalah berakar tunjang seperti jati, mangga, nangka, dan lain-lain. Namun terdapat pula tumbuhan berakar serabut seperti bambu. Bagian lereng yang agak datar dengan luasan yang terbatas, lahan dimanfaatkan untuk menanam seperti : ketela pohon, kacang, ubi jalar, dan tanaman kebutuhan rumah tangga lainnya.

\subsection{Kondisi Aktivitas Masyarakat Desa Tipar Kidul Pemanfaatan lahan}

Pemanfaatan lahan di Desa Tipar Kidul adalah untuk pemukiman, untuk pertanian dan perkebunan, 
banguan sekolah dan perkantoran desa, serta dimanfaatkan untuk pabrik industri.Pemukiman, bangunan sekolah dan perkantoran desa pada umumnya terletak di bagian lahan agak datar atau merupakan lahan hasil pemotongan lereng. Letak bangunan sangat dekat dengan lereng - lereng dengan kemiringan yang relatif landai dengan kemiringan antara $0-20 \%$. Demikian pula pabrik industri, berada pada lereng yang relatif landai dan bersebelahan dengan rumah penduduk. Lahan pertanian tidak ada zona khusus, umumnya lahan pertanian menggunakan terasering sederhana dan tidak membedakan besarnya kemiringan lereng. Sistem drainase terlihat ditepi jalan dengan konstruksi sederhana dengan batu kali.

\section{Pola tanam}

Penduduk Desa Tipar Kidul sebagian besar adalah petani. Pertanian pada umumnya adalah pertanian tanah kering dengan memanfaatkan lereng - lereng. Lereng ditanami dengan pola tanam yang tidak teratur dengan jenis tanaman yang beragam.

\section{Penggalian dan pemotongan lereng}

Penggalian dan pemotongan lereng di Desa Tipar Kidul dilakukan untuk jalan atau bangunan dan pembangunan dengan intensitas sedang, tetapi kegiatan ini belum mempertimbangkan struktur pelapisan tanah/batuandan perhitungan analisis kestabilan lereng.

\section{Pencetakan kolam}

Pengamatan di lapangan tidak ditemukan adanya pencetakan kolam di lereng. Lahan basah berupa sawah tadah hujan terdapat di beberapa tempat dengan luasan yang kecil dan tidak terkonsentrasi pada suatu tempat.

\section{Drainase}

Sistem drainase di Desa Tipar Kidul pada umumnya sudah cukup memadai. Hal ini terlihat di hampir sepanjang jalan Desa Tipar Kidul sudah ada bangunan drainase namun dengan kondisi yang kurang terawat.

\section{Pembangunan konstruksi}

Pembangunan konstruksi di Desa Tipar Kidul adalah untuk peruntukan perumahan, bangunan sekolah, perkantoran desa, pabrik industri, serta pertanian dan perkebunan. Bangunan konstruksi pada umumnya terletak dibagian lahan agak datar atau hasil pemotongan lereng. Beberapa bangunan tereletak sangat dekat dengan lereng - lereng dengan kemiringan yang cukup terjal.

\section{Kepadatan penduduk}

Menurut BPS Kabupaten Banyumas luas wilayah Desa Tipar Kidul adalah 1020,14 ha, yang terdiri dari 10 Dusun, 13 RW dan 62 RT dengan jumlah penduduk 11.081 orang. (BPS Kabupaten Banyumas).

\section{Usaha mitigasi}

Usaha - usaha mitigasi untuk mengurangi risiko terjadinya bencana tanah longsor di Desa Tipar Kidul sudah ada, baik oleh pemerintah daerah maupun masyarakat. Tetapi belum terkoordinasi dengan baik. Dengan demikian sensitivitas tingkat kerawanan longsor Desa Tipar Kidul tergolong sedang.

\subsection{Hasil Pembahasan}

Tabel 1. Kriteria dan indikator tingkat kerawanan aspek fisik alami zona berpotensi longsor Tipe C Desa Tipar Kidul (Titik 1)

\begin{tabular}{|c|c|c|c|c|c|c|}
\hline \multicolumn{7}{|c|}{ C1 Kriteria Aspek Fisik Alami } \\
\hline No & Indikator & $\begin{array}{l}\text { Bobot } \\
\text { Indikator } \\
(\%)\end{array}$ & $\begin{array}{l}\text { Sensitivitas } \\
\text { Tingkat } \\
\text { Kerawanan }\end{array}$ & Veriver & $\begin{array}{c}\text { Bobot } \\
\text { Penilaian }\end{array}$ & $\begin{array}{c}\text { Nilai Bobot } \\
\text { Tertimbang } \\
\text { Kerawanan } \\
\text { Longsor } \\
\end{array}$ \\
\hline-1 & -2 & -3 & -4 & -5 & -6 & -7 \\
\hline 1 & $\begin{array}{l}\text { Kemiringan } \\
\text { Lereng }\end{array}$ & $30 \%$ & Rendah & Kemiringan lereng 0-8\%. & 1 & 0,3 \\
\hline 2 & Kondisi Tanah & $15 \%$ & Rendah & $\begin{array}{l}\text { Lereng tersusun oleh batuan dan tanah } \\
\text { jenis latosol yang berwarna coklat } \\
\text { kemerahan, namun tidak ada struktur } \\
\text { retakan/kekar pada batuan. }\end{array}$ & 1 & 0,15 \\
\hline 3 & $\begin{array}{c}\text { Batuan Penyusun } \\
\text { Lereng }\end{array}$ & $20 \%$ & Tinggi & $\begin{array}{l}\text { Lereng tersusun oleh batuan batu } \\
\text { formasi halang yaitu jenis tanah batu } \\
\text { pasir andesit, konglomerat tufan dan } \\
\text { napal, bersisipan batu pasir. Di atas }\end{array}$ & 3 & 0,6 \\
\hline
\end{tabular}




\begin{tabular}{|c|c|c|c|c|c|c|}
\hline & & & & $\begin{array}{l}\text { bidang perlapisan batu pasir terdapat } \\
\text { bekas-bekas cacing. }\end{array}$ & & \\
\hline & & & & $\begin{array}{l}\text { Curah hujan mencapai } 70 \mathrm{~mm} / \mathrm{jam} \text { atau } \\
100 \mathrm{~mm} / \mathrm{hari} \text { curah hujan tahunan } \\
\text { mencapai lebih dari } 2500 \mathrm{~mm} / \mathrm{th} \text { yaitu }\end{array}$ & & \\
\hline 4 & Curah Hujan & $15 \%$ & Tinggi & $\begin{array}{l}2655 \mathrm{~mm} / \text { th yang didapat dari stasiun } \\
\text { penangkaran hujan bendung tajum, } \\
\text { sehingga debit sungai dapat meningkat } \\
\text { dan mengerosi kaki tebing sungai. }\end{array}$ & 3 & 0,6 \\
\hline 5 & Tata Air Lereng & $7 \%$ & Sedang & $\begin{array}{l}\text { Jarang muncul rembesan- rembesan air } \\
\text { atau mata air pada lereng atau bidang } \\
\text { kontak antara batuan kedap dengan } \\
\text { lapisan tanah yang permeable. }\end{array}$ & 2 & 0,14 \\
\hline 6 & Kegempaan & $3 \%$ & Rendah & $\begin{array}{l}\text { Lereng tidak termasuk daerah rawan } \\
\text { gempa. }\end{array}$ & 1 & 0,03 \\
\hline 7 & Vegetasi & $10 \%$ & Tinggi & $\begin{array}{l}\text { Tumbuhan semak, ketela pohon, pohon } \\
\text { pisang. }\end{array}$ & 3 & 0,03 \\
\hline & Jumlah Bobot & $100 \%$ & & & & 1,85 \\
\hline
\end{tabular}

Tabel 2. Kriteria dan indikator tingkat kerawanan aspek aktivitas manusia zona berpotensi longsor Tipe C Desa Tipar Kidul (Titik 1)

\begin{tabular}{|c|c|c|c|c|c|c|}
\hline \multicolumn{7}{|c|}{ C2 Kriteria Aspek Aktivitas Manusia } \\
\hline No & Indikator & $\begin{array}{l}\text { Bobot } \\
\text { Indikator } \\
\quad(\%)\end{array}$ & $\begin{array}{l}\text { Sensitivitas } \\
\text { Tingkat } \\
\text { Kerawanan }\end{array}$ & Veriver & $\begin{array}{c}\text { Bobot } \\
\text { Penilaian }\end{array}$ & $\begin{array}{c}\text { Nilai Bobot } \\
\text { Tertimbang } \\
\text { Kerawanan } \\
\text { Longsor } \\
\end{array}$ \\
\hline-1 & -2 & -3 & -4 & -5 & -6 & -7 \\
\hline 1 & Pola Tanam & $10 \%$ & Tinggi & $\begin{array}{l}\text { Lereng ditanami dengan pola tanaman } \\
\text { yang tidak tepat dan sangat sensitif, } \\
\text { berupa tanaman perkebunan seperti } \\
\text { ketela dan pohon pisang yang memiliki } \\
\text { akar yang kecil dan tidak cukup kokoh } \\
\text { menjaga struktur tananh tetap kuat. }\end{array}$ & 3 & 0,3 \\
\hline 2 & $\begin{array}{l}\text { Penggalian dan } \\
\text { Pemotongan } \\
\text { Lereng }\end{array}$ & $20 \%$ & Tinggi & $\begin{array}{l}\text { Intensitas penggalian/pemotongan } \\
\text { lereng tinggi yang digunakan untuk } \\
\text { bangunan rumah tinggal tanpa } \\
\text { memperhatikan struktur }\end{array}$ & 3 & 0,6 \\
\hline 3 & $\begin{array}{l}\text { Pencetakan } \\
\text { Kolam }\end{array}$ & $10 \%$ & Rendah & Tidak melakukan pencetakan kolam. & 1 & 0,1 \\
\hline 4 & Drainase & $10 \%$ & Sedang & $\begin{array}{l}\text { Sistem drainase memadai berupa } \\
\text { pasangan batu, tetapi dalam kondisi } \\
\text { yang kurang terawat. }\end{array}$ & 2 & 0,2 \\
\hline 5 & $\begin{array}{l}\text { Pembangunan } \\
\text { Konstruksi }\end{array}$ & $20 \%$ & Sedang & $\begin{array}{l}\text { Dilakukan pembangunan konstruksi dan } \\
\text { beban yang masih sedikit, tetapi belum } \\
\text { melampaui daya dukung tanah } \\
\text { (bangunan } 1 \text { lantai pada tanah } \\
\text { lempung). }\end{array}$ & 2 & 0,4 \\
\hline 6 & $\begin{array}{l}\text { Kepadatan } \\
\text { Penduduk }\end{array}$ & $20 \%$ & Rendah & $\begin{array}{l}\text { Kepadatan penduduk rendah }(<20 \\
\text { jiwa/ha). Yaitu 9,2471 jiwa/ha }\end{array}$ & 1 & 0,3 \\
\hline 7 & Usaha Mitigasi & $10 \%$ & Sedang & $\begin{array}{l}\text { Terdapat usaha mitigasi bencana tapi } \\
\text { belum terkoordinasi dan melembaga. }\end{array}$ & 2 & 0,2 \\
\hline & Jumlah Bobot & $100 \%$ & & & & 2,1 \\
\hline
\end{tabular}

Sumber: Analisis 2020

Tabel 3. Kriteria dan indikator tingkat kerawanan aspek fisik alami zona berpotensi longsor Tipe C Desa Tipar Kidul (Titik 2)

\begin{tabular}{|c|c|c|c|c|c|c|}
\hline \multicolumn{7}{|c|}{ C1 Kriteria Aspek Fisik Alami } \\
\hline No & Indikator & $\begin{array}{l}\text { Bobot } \\
\text { Indikator } \\
\quad(\%)\end{array}$ & $\begin{array}{l}\text { Sensitivitas } \\
\text { Tingkat } \\
\text { Kerawanan }\end{array}$ & Veriver & $\begin{array}{c}\text { Bobot } \\
\text { Penilaian }\end{array}$ & $\begin{array}{c}\text { Nilai Bobot } \\
\text { Tertimbang } \\
\text { Kerawanan } \\
\text { Longsor } \\
\end{array}$ \\
\hline-1 & -2 & -3 & -4 & -5 & -6 & -7 \\
\hline 1 & $\begin{array}{l}\text { Kemiringan } \\
\text { Lereng }\end{array}$ & $30 \%$ & Sedang & Kemiringan lereng 9-15\%. & 2 & 0,6 \\
\hline 2 & Kondisi Tanah & $15 \%$ & Rendah & $\begin{array}{l}\text { Lereng tersusun oleh batuan dan tanah } \\
\text { jenis latosol dan aluvial yang } \\
\text { berwarna coklat kemerahan, namun } \\
\text { tidak ada struktur retakan/kekar pada }\end{array}$ & 1 & 0,15 \\
\hline
\end{tabular}




\begin{tabular}{|c|c|c|c|c|c|c|}
\hline & & & & batuan. & & \\
\hline 3 & $\begin{array}{l}\text { Batuan Penyusun } \\
\text { Lereng }\end{array}$ & $20 \%$ & Tinggi & $\begin{array}{l}\text { Lereng tersusun oleh batuan batu } \\
\text { formasi halang yaitu jenis tanah batu } \\
\text { pasir andesit, konglomerat tufan dan } \\
\text { napal, bersisipan batu pasir. Di atas } \\
\text { bidang perlapisan batu pasir terdapat } \\
\text { bekas-bekas cacing. }\end{array}$ & 3 & 0,6 \\
\hline 4 & Curah Hujan & $15 \%$ & Tinggi & $\begin{array}{l}\text { Curah hujan mencapai } 70 \mathrm{~mm} / \mathrm{jam} \\
\text { atau } 100 \mathrm{~mm} / \text { hari curah hujan tahunan } \\
\text { mencapai lebih dari } 2500 \mathrm{~mm} / \mathrm{th} \text { yaitu } \\
2655 \mathrm{~mm} / \text { th yang didapat dari stasiun } \\
\text { penangkaran hujan bendung tajum. }\end{array}$ & 3 & 0,6 \\
\hline 5 & Tata Air Lereng & $7 \%$ & Sedang & $\begin{array}{l}\text { Jarang muncul rembesan- rembesan } \\
\text { air atau mata air pada lereng atau } \\
\text { bidang kontak antara batuan kedap } \\
\text { dengan lapisan tanah yang permeable. }\end{array}$ & 2 & 0,14 \\
\hline 6 & Kegempaan & $3 \%$ & Rendah & $\begin{array}{l}\text { Lereng tidak termasuk daerah rawan } \\
\text { gempa. }\end{array}$ & 1 & 0,03 \\
\hline \multirow[t]{2}{*}{7} & Vegetasi & $10 \%$ & Tinggi & $\begin{array}{l}\text { Tumbuhan semak, alang- alang, pohon } \\
\text { pisang. }\end{array}$ & 3 & 0,03 \\
\hline & Jumlah Bobot & $100 \%$ & & & & 2,15 \\
\hline
\end{tabular}

Tabel 4. Kriteria dan indikator tingkat aspek aktivitas manusia zona berpotensi longsor Tipe C

Desa Tipar Kidul (Titik 2)

\begin{tabular}{|c|c|c|c|c|c|c|}
\hline \multicolumn{7}{|c|}{ C2 Kriteria Aspek Aktivitas Manusia } \\
\hline No & Indikator & $\begin{array}{l}\text { Bobot } \\
\text { Indikator } \\
\quad(\%)\end{array}$ & $\begin{array}{l}\text { Sensitivitas } \\
\text { Tingkat } \\
\text { Kerawanan }\end{array}$ & Veriver & $\begin{array}{c}\text { Bobot } \\
\text { Penilaian }\end{array}$ & $\begin{array}{c}\text { Nilai Bobot } \\
\text { Tertimbang } \\
\text { Kerawanan } \\
\text { Longsor }\end{array}$ \\
\hline-1 & -2 & -3 & -4 & -5 & -6 & -7 \\
\hline 1 & Pola Tanam & $10 \%$ & Tinggi & $\begin{array}{l}\text { Lereng ditanami dengan pola tanaman } \\
\text { yang tidak tepat dan sangat sensitif, } \\
\text { berupa alang-alang, tumbuhan semak } \\
\text { serta tanaman perkebunan seperti } \\
\text { pohon pisang. } \\
\text { Intensitas penggalian/pemotongan }\end{array}$ & 3 & 0,3 \\
\hline 2 & $\begin{array}{l}\text { Penggalian dan } \\
\text { Pemotongan } \\
\text { Lereng }\end{array}$ & $20 \%$ & Tinggi & $\begin{array}{l}\text { lereng tinggi yang digunakan untuk } \\
\text { bangunan rumah tinggal tanpa } \\
\text { memperhatikan struktur perlapisan } \\
\text { tanah/batuan pada lereng dan tanpa } \\
\text { perhitungan analisis kestabilan lereng. }\end{array}$ & 3 & 0,6 \\
\hline 3 & $\begin{array}{l}\text { Pencetakan } \\
\text { Kolam }\end{array}$ & $10 \%$ & Rendah & Tidak melakukan pencetakan kolam. & 1 & 0,1 \\
\hline 4 & Drainase & $10 \%$ & Tinggi & $\begin{array}{l}\text { Sistem drainase tidak memadai dan } \\
\text { tidak ada usaha-usaha untuk } \\
\text { memperbaiki. }\end{array}$ & 3 & 0,3 \\
\hline 5 & $\begin{array}{l}\text { Pembangunan } \\
\text { konstruksi }\end{array}$ & $20 \%$ & Sedang & $\begin{array}{l}\text { Dilakukan pembangunan konstruksi } \\
\text { dan beban yang masih sedikit, tetapi } \\
\text { belum melampaui daya dukung } \\
\text { (bangunan } 1 \text { lantai pada tanah } \\
\text { lempung). }\end{array}$ & 2 & 0,4 \\
\hline 6 & $\begin{array}{l}\text { Kepadatan } \\
\text { Penduduk }\end{array}$ & $20 \%$ & Rendah & $\begin{array}{l}\text { Kepadatan penduduk rendah }(<20 \\
\text { jiwa/ha). Yaitu 9,2471 jiwa/ha }\end{array}$ & 1 & 0,3 \\
\hline 7 & Usaha Mitigasi & $10 \%$ & Sedang & $\begin{array}{l}\text { Terdapat usaha mitigasi bencana tapi } \\
\text { belum terkoordinasi dan melembaga. }\end{array}$ & 2 & 0,2 \\
\hline & Jumlah Bobot & $100 \%$ & & & & 2,2 \\
\hline
\end{tabular}

Sumber: Analisis 2020

Tabel 5. Kriteria dan indikator tingkat kerawanan aspek fisik alami zona berpotensi longsor Tipe C

Desa Tipar Kidul (Titik 3)

\begin{tabular}{|c|c|c|c|c|c|c|}
\hline \multicolumn{7}{|c|}{ C1 Kriteria Aspek Fisik Alami } \\
\hline No & Indikator & $\begin{array}{c}\text { Bobot } \\
\text { Indikator } \\
(\%)\end{array}$ & $\begin{array}{c}\text { Sensitivitas } \\
\text { Tingkat } \\
\text { Kerawanan }\end{array}$ & Veriver & $\begin{array}{c}\text { Bobot } \\
\text { Penilaian }\end{array}$ & $\begin{array}{c}\text { Nilai Bobot } \\
\text { Tertimbang } \\
\text { Kerawanan } \\
\text { Longsor } \\
\end{array}$ \\
\hline-1 & -2 & -3 & -4 & -5 & -6 & -7 \\
\hline 1 & Kemiringan & $30 \%$ & Tinggi & Kemiringan lereng $16-20 \%$. & 3 & 0,9 \\
\hline
\end{tabular}




\begin{tabular}{|c|c|c|c|c|c|c|}
\hline \multicolumn{7}{|c|}{ Lereng } \\
\hline 2 & Kondisi Tanah & $15 \%$ & Rendah & $\begin{array}{l}\text { Lereng tersusun oleh batuan dan tanah } \\
\text { jenis latosol dan aluvial yang berwarna } \\
\text { coklat kemerahan, namun tidak ada } \\
\text { struktur retakan/kekar pada batuan. }\end{array}$ & 1 & 0,15 \\
\hline 3 & $\begin{array}{c}\text { Batuan Penyusun } \\
\text { Lereng }\end{array}$ & $20 \%$ & Tinggi & $\begin{array}{l}\text { Lereng tersusun oleh batuan batu } \\
\text { formasi halang yaitu jenis tanah batu } \\
\text { pasir andesit, konglomerat tufan dan } \\
\text { napal, bersisipan batu pasir. Di atas } \\
\text { bidang perlapisan batu pasir terdapat } \\
\text { bekas-bekas cacing. }\end{array}$ & 3 & 0,6 \\
\hline 4 & Curah Hujan & $15 \%$ & Tinggi & $\begin{array}{l}\text { Curah hujan mencapai } 70 \mathrm{~mm} / \mathrm{jam} \text { atau } \\
100 \mathrm{~mm} / \text { hari curah hujan tahunan } \\
\text { mencapai lebih dari } 2500 \mathrm{~mm} / \mathrm{th} \text { yaitu } \\
2655 \mathrm{~mm} / \text { th yang didapat dari stasiun } \\
\text { penangkaran hujan bendung tajum. }\end{array}$ & 3 & 0,6 \\
\hline 5 & Tata Air Lereng & $7 \%$ & Rendah & $\begin{array}{l}\text { Tidak terdapat rembesan air atau mata } \\
\text { air pada lereng atau bidang kontak } \\
\text { antara batuan kedap dengan lapisan } \\
\text { tanah yang permeable. }\end{array}$ & 1 & 0,07 \\
\hline 6 & Kegempaan & $3 \%$ & Rendah & $\begin{array}{l}\text { Lereng tidak termasuk daerah rawan } \\
\text { gempa. }\end{array}$ & 1 & 0,03 \\
\hline 7 & Vegetasi & $10 \%$ & Tinggi & $\begin{array}{l}\text { Alang-alang, rumput- rumputan, } \\
\text { tumbuhan semak, tumbuhan perdu. }\end{array}$ & 3 & 0,03 \\
\hline & Jumlah Bobot & $100 \%$ & & & & 2,38 \\
\hline
\end{tabular}

Sumber : Analisis 2020

Tabel 6. Kriteria dan indikator tingkat aspek aktivitas manusia zona berpotensi longsor Tipe C

Desa Tipar Kidul (Titik 3)

\begin{tabular}{|c|c|c|c|c|c|c|}
\hline \multicolumn{7}{|c|}{ C2 Kriteria Aspek Aktivitas Manusia } \\
\hline No & Indikator & $\begin{array}{l}\text { Bobot } \\
\text { Indikator } \\
\quad(\%)\end{array}$ & $\begin{array}{l}\text { Sensitivitas } \\
\text { Tingkat } \\
\text { Kerawanan }\end{array}$ & Veriver & $\begin{array}{c}\text { Bobot } \\
\text { Penilaian }\end{array}$ & $\begin{array}{c}\text { Nilai Bobot } \\
\text { Tertimbang } \\
\text { Kerawanan } \\
\text { Longsor } \\
\end{array}$ \\
\hline-1 & -2 & -3 & -4 & -5 & -6 & -7 \\
\hline 2 & $\begin{array}{l}\text { Penggalian dan } \\
\text { Pemotongan } \\
\text { Lereng }\end{array}$ & $20 \%$ & Tinggi & $\begin{array}{l}\text { Lereng ditanami dengan pola tanaman } \\
\text { yang tidak tepat dan sangat sensitif, } \\
\text { berupa tumbuhan semak yang memiliki } \\
\text { akar yang kecil dan tidak cukup kokoh } \\
\text { menjaga struktur tanah tetap kuat. } \\
\text { Intensitas penggalian/pemotongan lereng } \\
\text { tinggi yang digunakan untuk bangunan } \\
\text { rumah tinggal dan jalan tanpa } \\
\text { memperhatikan struktur perlapisan } \\
\text { tanah/batuan pada lereng dan tanpa } \\
\text { perhitungan analisis kestabilan lereng. }\end{array}$ & 3 & 0,3 \\
\hline 3 & $\begin{array}{l}\text { Pencetakan } \\
\text { Kolam }\end{array}$ & $10 \%$ & Rendah & Tidak melakukan pencetakan kolam. & 1 & 0,1 \\
\hline 4 & Drainase & $10 \%$ & Sedang & $\begin{array}{l}\text { Sistem drainase memadai berupa } \\
\text { pasangan batu, tetapi dalam kondisi yang } \\
\text { kurang terawat. }\end{array}$ & 2 & 0,2 \\
\hline 5 & $\begin{array}{l}\text { Pembangunan } \\
\text { konstruksi }\end{array}$ & $20 \%$ & Sedang & $\begin{array}{l}\text { Dilakukan pembangunan konstruksi dan } \\
\text { beban yang masih sedikit, tetapi belum } \\
\text { melampaui daya dukung (bangunan } 1 \\
\text { lantai pada tanah lempung). }\end{array}$ & 2 & 0,4 \\
\hline 6 & $\begin{array}{l}\text { Kepadatan } \\
\text { Penduduk }\end{array}$ & $20 \%$ & Rendah & $\begin{array}{l}\text { Kepadatan penduduk rendah }(<20 \\
\text { jiwa/ha). Yaitu } 9,2471 \text { jiwa/ha }\end{array}$ & 1 & 0,3 \\
\hline 7 & Usaha Mitigasi & $10 \%$ & Sedang & $\begin{array}{l}\text { Terdapat usaha mitigasi bencana tapi } \\
\text { belum terkoordinasi dan melembaga. }\end{array}$ & 2 & 0,2 \\
\hline & Jumlah Bobot & $100 \%$ & & & & 2,1 \\
\hline
\end{tabular}

Sumber : Analisis 2020

\section{Hasil analisis perhitungan}

Hasil analisis titik 1 zona berpotensi longsor tipe c :
a) Aspek fisik alami total nilai bobot tertimbang
$=1,85$
b) Aspek aktifitas manusia total nilai bobot tertimbang
$=2,1$
c) Tingkat kerawanan zona berpotensi longsor
$=(1,85+2,1) / 2=1,975$ 
Dengan demikian tingkat kerawanan zona berpotensi longsor di titik 1 Desa Tipar Kidul adalah sedang.

Hasil analisis titik 2 zona berpotensi longsor tipe $\mathbf{c}$ :
a) Aspek fisik alami total nilai bobot tertimbang
$=2,15$
b) Aspek aktifitas manusia total nilai bobot tertimbang
$=2,2$
c) Tingkat kerawanan zona berpotensi longsor
$=(2,15+2,2) / 2=2,175$

Dengan demikian tingkat kerawanan zona berpotensi longsor di titik 2 Desa Tipar Kidul adalah sedang.

Hasil analisis titik 3 zona berpotensi longsor tipe $\mathbf{c}$ :

a) Aspek fisik alami total nilai bobot tertimbang

$$
\begin{aligned}
& =2,38 \\
& =2,1 \\
& =(2,38+2,1) / 2=2,24
\end{aligned}
$$

b) Aspek aktifitas manusia total nilai bobot tertimbang

c) Tingkat kerawanan zona berpotensi longsor

Dengan demikian tingkat kerawanan zona berpotensi longsor di titik 3 Desa Tipar Kidul adalah sedang.

\begin{tabular}{ccc} 
Tabel 7. Tingkat kerawanan zona berpotensi longsor Desa Tipar Kidul \\
\cline { 2 - 3 } $\begin{array}{c}\text { Lokasi } \\
\text { pengamatan }\end{array}$ & $\begin{array}{c}\text { Total nilai bobot } \\
\text { tertimbang }\end{array}$ & $\begin{array}{c}\text { Sensitivitas tingkat } \\
\text { kerawanan }\end{array}$ \\
\hline Titik 1 & 1,975 & Sedang \\
Titik 2 & 2,175 & Sedang \\
Titik 3 & 2,24 & Sedang \\
\hline Sumber : Analisis 2020 & &
\end{tabular}

Dari hasil ke-tiga titik pengamatan pada tabel diatas menunjukan sensitivitas tingkat kerawanan pada setiap titik tergolong sedang, sehingga tingkat kerawanan longsor lereng di Desa Tipar Kidul Kecamatan Ajibarang tergolong sedang.

\section{KESIMPULAN}

\section{Kesimpulan}

Kesimpulan Berdasarkan hasil penelitian, analisis data maupun pembahasan tipologi zona berpotensi longsor dan menentukan klasifikasi tingkat kerawanan terhadap longsor di Desa Tipar kidul Kecamatan Ajibarang dapat diambil keismpulan sebagai berikut: Hasil analisis dari ke-tiga titik pengamatan total nilai bobot tertimbang berdasarkan aspek fisik alami dan aspek aktivitas manusia diperoleh nilai ; titik $1=1,975$ (sedang), titik $2=2,175$ (sedang), dan titik $3=2,24$ (sedang). Sehingga tingkat kerawanan zona berpotensi longsor di Desa Tipar Kidul Kecamatan Ajibarang adalah tergolong sedang.

\section{Saran}

1. Perlu dilakukan penelitian lebih lanjut dengan mengambil lokasi penelitian yang lebih spesifik karena dalam penelitian ini lokasi yang dianalisis mencakup wilayah Desa Tipar Kidul secara umum.

2. Perlu dilakukan penelitian lebih lanjut yaitu dengan cara melakukan survei langsung karena pada penelitian ini beberapa data diperoleh menggunakan aplikasi bantu yaitu Arc GIS sehingga dapat digunakan pembanding antara metode survei langsung dengan metode yang menggunakan aplikasi bantu Arc GIS.

\section{DAFTAR PUSTAKA}

[1] Anonim. (2007). Undang-Undang No. 24 Tahun 2007 tentang Penanggulangan Bencana.

[2] Arikunto, S., 1996, Prosedur Penelitian Suatu Pendekatan Praktek, Penerbit Asdi Mahastya, Jakarta.

[3] Badan Pusat Statistik 2018 Kecamatan Ajibarang Dalam Angka Diakses pada https://banyumaskab.bps.go.id/publication/2018/09/26/36502a5b4933985f9e42387a/kecamatan-ajibarang-dalam angka-2018.html

[4] BPBD Kabupaten Banyumas, 2012, Profil Bencana Kabupaten Banyumas.

[5] Direktorat Jenderal Penataan Ruang, 2007, Pedoman Penataan Ruang Kawasan Rawan Bencana Longsor, Departemen Pekerjaan Umum, Jakarta.

[6] Dudal, R. dan M. Soepraptohardjo. 1957. Soil Classification in Indonesia. Cont. Gen. Agr. Res. Sta. No. 148. Bogor.

[7] Direktorat Jenderal Penataan Ruang, 2008, Modul Terapan Pedoman Penataan Ruang Kawasan Rawan Bencana Longsor, Departemen Pekerjaan Umum, Jakarta.

[8] Hardiyanto, H., C.,2001, Analisis Sebab-sebab Kelongsoran Lereng di Purworejo dan Sekitarnya, Jurnal Forum Teknik Sipil, Vol. X/1-Januari 2001, Jurusan Teknik Sipil, Fakultas Teknik, Universitas Gadjah Mada, Yogyakarta.

[9] Jayadinata, J.T. 1999, Tata Guna Tanah Dalam Perencanaan Pedesaan Perkotaan dan Wilayah. Bandung : Penerbit ITB.

[10] Karnawati, D. 2003, Manajemen Bencana Gerakan Tanah. Diktat Kuliah.

[11] Yogyakarta : Jurusan Teknik Geologi, Universitas Gadjah Mada.

[12] Lepore, C., Arnone, E., Noto, L. V., Sivandran, G., \& Bras, R. L. (2013). Physically based modeling of rainfall-triggered 
landslides: a case study in the Luquillo forest, Puerto Rico. Hydrology and Earth System Sciences, 17(9), 3371 - 3387.

[13] Ponziani, F., Pandolfo, C., Stelluti, M., Berni, N. Brocca, L. \& Moramarco, T. (2012). Assessment of rainfall thresholds and soil moisture modeling for operational hydrogeological risk prevention in the Umbria region (Central Italy). Landslides, 9(2), 229237.

[14] Radar Banyumas. 2016. Bencana Longsor Intai Banyumas. Diakses pada https://radarbanyumas.co.id/bencana-longsorintai-banyumas/

[15] Soil Survey Staff. 2014. Keys to Soil Taxonomy. Twelfth Edition. United States Department of Agriculture-Natural Resources Conservation Service. Washington, D.C.

[16] Suranto, J.P, 2008, Kajian Pemanfaatan Lahan Pada Daerah Rawan Bencana Tanah Longsor di Kecamatan Cilongok Kabupaten Banyumas.

[17] Suryolelono, K.B., 2002, Bencana Alam Tanah Longsor Perspektif Ilmu Geoteknik, Pidato Pengukuhan Guru Besar Pada Fakultas Teknik Universitas Gadjah Mada, Ygyakarta.

[18] Suripin, 2002. Pelestarian Sumber Daya Tanah dan Air. Yogyakarta : Penerbit Andi.

[19] Sutomo, dan Esti Sarjanti, 2007, Analisis Risiko Longsor Lahan Dengan Pendekatan Landscape Ecologycal Risk Information System (LERIS) di Kecamatan Somagede Kabupaten Banyumas, Laporan Dosen Muda, LPPM UMP, Purwokerto.

[20] Suwarno, dan Sutomo, 2006, Mitigasi Bahaya Longsor Lahan di Kecamatan Gumelar Kabupaten Banyumas, Laporan Penelitian Bidang Studi, LPPM UMP, Purwokerto.

[21] Varnes, D.J. 1978. Slope Movement and Type and Processes, Landslide Analysis and Control. Transportation Research Board, Special Report 176, Washington D.C. National Research Council. 